\title{
Evolution of the First Italian Corporate Accelerator*
}

\author{
Ilaria Potito**
}

\begin{abstract}
Launched in 2009 with the name "Working Capital", when in Italy these themes were not much discussed, TIM \#Wcap Accelerator has had a leading role in the evolution and growth of the innovation ecosystem in our country, so that today it has become the most significant Italian corporate accelerator selecting, financing and accelerating the best digital start-ups each year.
\end{abstract}

Keywords: \#Wcap; Corporate Accelerator; Open Innovation; Global Markets; Start-up Ecosystem; TIM

\section{Accelerator and Innovation}

Talented people move, competencies need space and dynamic realities. Goods and services require continuous research, while markets and economic models change very fast. These are the conditions for Open Innovation. As a matter of fact, today it is possible to innovate not only by using internal resources, namely R\&D labs, but also with an eye to external resources, paying special attention to ideas and innovations generated outside. TIM's Digital Innovation is grounded in this paradigm and TIM \#Wcap Accelerator plays a pivotal role in a company's open innovation process.

\section{Working Capital}

TIM \#Wcap's earliest activities date back to 2010. In that year, nearly 70 research and business projects were financed. 2011 was the right moment to take a tour of Italy: indeed, this year marked the one hundred and fiftieth anniversary of the unification of Italy, and TIM \#Wcap launched the "Tour dei Mille" (named after Garibaldi's Expedition of the Thousand of 1861). Thus, 1,000 projects were selected and evaluated from a total of over 2,000, and 40 of these were eventually financed. 2013 marked a turning point, as three new accelerators opened in Milan, Rome and Catania. In 2014, a fourth followed, this time in Bologna.

\footnotetext{
* Invited Article

** Head of TIM \#Wcap Accelerator (ilaria.potito@ telecomitalia.it)
} 
These were also the years in which the current "call for the start-up system" was established, in turn replacing the old "call for ideas", whereby the selected digital start-ups are assigned a grant - for an amount of 25,000 Euros until 2015 and of 40,000 Euros in 2016 - and awarded an acceleration program, mentorship and coworking for the duration of twelve months in one of the four Italian accelerators in Milan, Bologna, Rome or Catania.

In 2014, with the progressive growth of the Italian innovation ecosystem and the development, albeit slow, of the digital economy, TIM \#Wcap began repositioning itself. The specialized press and the various actors in the ecosystem drew attention to the pressing economic and legal issues, pointing out the need for investments and asking politicians to commit themselves to help foster the growth of innovative companies: indeed, start-ups need support, trust and contracts. The digital transformation process, which is an obvious reality for any nation that wants to be in step with the times, needs public as well as private support. In Italy, innovation has finally become a serious theme of discussion, touching on our country's vision and future. Of course, this does not imply that solutions are at hand, but that undoubtedly many have finally recognized that there are a number of issues that need to be addressed and solved.

In this scheme, TIM \#Wcap occupies the position of corporate accelerator: a business accelerator controlled by the seventh largest Italian company by revenue, a company that could profitably use to its own advantage the business solutions developed for the digital start-ups; a corporate accelerator whose sheer dimensions and capability to promote business make it an extraordinary example of Open Innovation for companies.

\section{How to Structure Innovation: Community, Scouting, Selection, Acceleration}

TIM \#Wcap is now in its seventh year. As said above, over the years it turned from a farsighted and pioneering project aimed at structuring innovation, creating a community of Italian innovators, selecting, and financing highly promising startups, into a full-scale industrial Open-Innovation program, introduced in a mature and competitive ecosystem. Expressed in figures, these seven years represent a treasure of data and evidence from which can be drawn information that may be valuable also in the future:

- more than 5.5 million Euros awarded to start-ups;

- more than 8,000 projects collected;

- 4,000 square meters dedicated to innovation activities in the four accelerators in Milan, Bologna, Rome, and Catania;

- 260 start-ups supported;

- in the last two years more than thirty contracts have been signed between independent start-ups and branches of the TIM group;

- between 2014 and 2015, TIM Ventures invested in eleven TIM \#Wcap accelerated start-ups. 
Innovation does not appear from nowhere: it needs to be channeled, to be structured. TIM \#Wcap has been playing an in important role in the construction of the Italian innovation ecosystem, contributing to the creation of communities of innovators throughout Italy. It has been doing so first by traveling, that is, organizing a tour in Italy and searching for talents and ideas; then, from 2013 onward, with the opening of four important facilities that are meeting points and have now become catalysts of some of the most significant experiences of innovation in the country. Especially, but non exclusively, during the call for startups, TIM \#Wcap scouts for new talents: the ensuing exchange of information and feedback with the start-ups contribute to enriching TIM \#Wcap's deal flow, but also spreads the culture of entrepreneurship and innovation, which is one of the most socially relevant aspects of TIM's corporate accelerator.

In the two months while the call is still open, hundreds of events and meetings are organized to promote it all over Italy, so that start-uppers and local innovators can meet and receive support from the TIM \#Wcap's staff in cities different from those hosting the four main accelerators: these events span from weekly open days organized in the four main accelerators to the participation to meetings organized in higher-education institutions, from TEDx to Start-up Weekend, Start-up Grind, Codemotion, Barcamp, and other initiatives organized by the local association or at the university.

The scouting phase is followed by a process of evaluation articulated in various stages: the best start-ups selected then receive a grant and are admitted to the Digital Innovation Year - a twelve-month program, three of which are devoted to the process of acceleration and the extant nine months to mentorship and coworking.

The acceleration program takes place simultaneously in the four accelerators, where the start-ups are guided at best in the defining their products/services until these are launched on the market. Experts in business and in other subjects connected to innovation lead the various phases of the program, which may take place in class or in one-to-one sessions.

Once the acceleration stage is over, the selected start-ups keep working in the accelerator's co-working spaces and benefiting from the TIM \#Wcap mentorship. During those months, they can also operate a "pivot", that is, they can do some adjustments to their initial business and "go to market" strategies.

During or at the end of the Digital Innovation Year, the best start-ups can become part of TIM's innovation portfolio, and can be chosen to be the object of investment on the part of the Corporate Venture Capital TIM Ventures.

At a quick glance, going over their names and quantity, we can safely affirm that at a certain moment, all the most important Italian start-ups have crossed path with TIM \#Wcap. The same can be said for many young entrepreneurs in the digital industry. Let me give you some examples.

Innaas (Innovation As Service), which joined TIM \#Wcap in 2014, is now leading the data driven approach of companies. Pedius, an app allowing the hearingimpaired to make phone calls, was the first Italian start-up to be included in the "start-ups with a social goal" roster. Oilproject is the largest Italian school online. And also: Unfraud, Eggup, Meritocracy, Cloudesire. You just need to go over the TIM \#Wcap start-up portfolio to realize how much innovation can be generated. In 
all cases, we are talking of projects managed by specific founders and first-rank teams keeping up with global tech trends.

TIM \#Wcap is strategically committed in the integration and in the establishment of a network that includes important partners such as accelerators, incubators, foundations, associations, and newspapers.

In the spirit of Open Innovation, aimed at benefiting companies and start-ups, TIM \#Wcap addresses two major issues: it finds future TIM suppliers and guides start-ups to enter the market, gives them industrial support, and help them close important investment rounds.

Perhaps, what a start-up can learn from a large company equals what a company can receive from young innovators working passionately as nowhere else: exchanges are key in Open Innovation. This is why we at TIM \#Wcap shall never get tired of thinking that innovation is always open.

\section{Bibliography}

Aspen Institute (2014). Measuring value created by impact incubators \& accelerators.

Arrigo, E. (2012). Alliances, Open Innovation and Outside-in Management, Symphonya. Emerging Issues in Management (symphonya.unimib.it), 2, 53-65 http://dx.doi.org/10.4468/2012.2.05arrigo

Brondoni, S.M. (2008). Market-Driven Management, Competitive Space and Global Networks, Symphonya. Emerging Issues in Management (symphonya.unimib.it), 1, 14-27

http://dx.doi.org/10.4468/2008.1.02brondoni

Brondoni, S.M. (2015). Global Networks, Outside-In Capabilities and Smart Innovation, Symphonya. Emerging Issues in Management (symphonya.unimib.it), 1, 6-21

http://dx.doi.org/10.4468/2015.1.02brondoni

Gnecchi, F. (2009). Market-Driven Management, Market Space and Value Proposition, Symphonya. Emerging Issues in Management (symphonya.unimib.it), 2, 33-45 http://dx.doi.org/10.4468/2009.2.04gnecchi

Grimaldi, R., Grandi, A. (2005). Business incubators and new venture creation: an assessment of incubating models. Technovation, 25(2): 111-121.

Hochberg, Y. V. (2015). Accelerating Entrepreneurs and Ecosystems: The Seed Accelerator Model, Innovation Policy and the Economy, Volume 16.

Miller P., Bound K. (2011). The Start-up Factories, Nesta Dicussion, Paper June.

Weiblen T., Henry W. Chesbrough H.W. (2015). Engaging with Start-ups to Enhance Corporate Innovation, California Management Review, 57 (2), Winter, 66-90.

Foxall, G. (2014). Corporate Innovation (RLE Marketing): Marketing and Strategy. Routledge.

Schweisfurth, T. G., \& Raasch, C. (2015). Embedded lead users-The benefits of employing users for corporate innovation. Research policy, 44(1), 168-180. 